\title{
How and When Managers Reward Employees' Voice: The Role of \\ Proactivity Attributions
}

\author{
Hyunsun Park \\ University of Maryland \\ hpark910@umd.edu \\ Subrahmaniam Tangirala \\ University of Maryland \\ stangira@umd.edu \\ Insiya Hussain \\ University of Texas at Austin \\ insiya.hussain@mccombs.utexas.edu \\ Srinivas Ekkirala \\ Indian Institute of Management Bangalore \\ srinivas.ekkirala@iimb.ac.in
}

In press

Journal of Applied Psychology

(C) 2022, American Psychological Association. This paper is not the copy of record and may not exactly replicate the final, authoritative version of the article. Please do not copy or cite without authors' permission. The final article will be available, upon publication, via its DOI: 10.1037/apl0001008

Author Note:

All data, analysis codes, and materials for all studies are available on a dedicated Open Science Framework (OSF) webpage (https://bit.ly/3hYPzKM). Pre-registration for Study 1 is available at https://aspredicted.org/hj8q9.pdf. The full text of Study 1's scenario, as well as all the measures and items used in the study, are available in Online Appendix A (https://bit.ly/3hYPzKM). An earlier version of this article was presented at the 2020 Annual Meeting of the Academy of Management (virtual).

The first author would like to thank Nicolais Chighizola for his encouragement and friendly review on the earlier version of this article. 


\title{
How and When Managers Reward Employees' Voice: The Role of Proactivity Attributions
}

\begin{abstract}
Recent voice research has noted that providing adequate job rewards for speaking up can sustainably motivate voice from employees. We examine why managers who seek out voice at work might not always properly reward the behavior. Drawing on theories of dispositional attribution, we propose that, in general, managers tend to reward voice because it signals to them that employees possess a valued underlying trait: proactivity, which is characterized by changeorientation and foresight. However, we argue that when managers engage in more voice solicitation - that is, explicitly ask for voice and take a listening posture toward it - their tendency to infer proactivity from employees' voice weakens. Thus, we make a case that voice solicitation, a managerial behavior intended to set facilitating conditions for speaking up at work, inadvertently weakens the (indirect) relationship between employee voice and job rewards. We establish support for our theory in a set of 2 studies with complementary designs. Study 1 was a pre-registered between-subjects experiment that used a realistic vignette design with an online panel of 592 working adults based in the United States. Study 2 was a multisource field survey with a sample of 385 employees and their managers working at the India branch of a global technology company in the oil and gas industry. We discuss the theoretical and practical implications of our results.
\end{abstract}

Keywords: Employee voice, voice solicitation, proactivity, leadership. 
Employees are uniquely positioned to spot and bring up work issues that otherwise may go unnoticed or be overlooked by managers higher in the organizational hierarchy (Edmondson, 2003). They can more closely observe opportunities or problems on the frontlines and develop ideas and solutions that managers often cannot (Li \& Tangirala, 2021a). Not surprisingly, voice, or employees' expression of constructive work ideas or concerns (Van Dyne \& LePine, 1998), helps teams reduce errors, improve worker safety, as well as increase innovation, resilience, and overall performance (Detert et al., 2013; Lam \& Mayer, 2014; Li et al., 2017; Li \& Tangirala, 2021b; MacKenzie et al., 2011).

Given such benefits, it is critical that managers reinforce favorable conditions for voice by ensuring that employees get adequate job rewards, such as higher salaries, public recognition, and promotions (Allen \& Rush, 1998), for speaking up. After all, desirable work behaviors can only be effectively maintained when their enactment is followed by rewards (Kerr, 1995). Indeed, recent studies have indicated that connecting voice with job rewards can be a helpful way of sustaining employees' motivation to speak up (e.g., Li \& Tangirala, 2021b). At the same time, however, meta-analyses have noted that there is variability in how managers respond to voice (Chamberlin et al., 2017), suggesting that voice is not always strongly positively associated with subsequent job rewards. We propose that research can better unpack this voice-job rewards relationship by more precisely specifying why managers would reward voice, if at all, and can further build on that foundation to highlight when they would do so.

We take a step into this direction by drawing on theories of dispositional attribution (e.g., Jones \& Davis, 1965; Trope, 1986) that can provide potent explanations for managers' job rewards decisions (Allen \& Rush, 1998; Eastman, 1994). These theories note that managers frequently draw inferences about employees' traits from their behaviors. Such trait attributions 
represent managers' lay causal inferences about the innate motivations behind employees' behaviors (Green \& Mitchell, 1979). Importantly, these attributions are the outcomes of managers' attempts to identify whether employees possess desirable traits and thus decide if it is worthwhile to invest in those employees by granting them job rewards such as salary increases, promotions, or high-profile assignments (Green \& Mitchell, 1979). From this perspective, the more that managers infer organizationally desirable traits from employees' behaviors, the more they become willing to reward those employees (Allen \& Rush, 1998). A key tenet driving trait attributions is the correspondence principle: The closer an employee comes to demonstrating behaviors that are prototypically associated with a well-known trait category, the more likely managers are to classify the employee in that trait category (Howard, 1985; Jones \& Davis, 1965). Voice, which involves the expression of ideas or concerns aimed at improving the status quo, is a behavior prototypically associated with proactivity, which represents change-orientation and foresight (Bindl \& Parker, 2010; Crant, 2000). Given that proactivity is a highly valued trait in the workplace (e.g., Grant \& Ashford, 2008), we argue that voice is rewarded by managers because it allows for their attributions of employees' proactivity underlying the behavior.

Furthermore, theories of dispositional attribution help us understand the conditions under which voice is more versus less strongly connected with managers' proactivity attributions and, thereby, their job rewards decisions. In addition to the correspondence principle, the discounting principle constitutes another key element of attribution theories (Green \& Mitchell, 1979; Ross, 1977; Trope, 1986). This principle posits that correspondent actor behaviors become more weakly associated with trait inferences when environmental facilitators of those behaviors are particularly visible to observers (Reeder \& Brewer, 1979). That is, when deducing traits from actors' behaviors, observers tend to cognitively subtract any presumed impact that discernable 
situational inducements might have on those behaviors (Ross 1977; Trope, 1986). In the context of voice, the actions that managers themselves have directly taken to encourage it, such as voice solicitation, or explicitly asking employees for voice and taking an active listening posture toward it (Fast et al., 2014; Sherf et al., 2019; Tangirala \& Ramanujam, 2012), would likely be most salient to the managers as situational inducements. Thus, following the discounting principle, we argue that the more managers engage in voice solicitation, the less likely they are to connect voice to employees' underlying proactivity and, accordingly, to job rewards. Through this argument, we present a potentially intriguing proposition that, ultimately, employees would gain comparatively lower rewards for similar levels of voice when managers encourage such voice than when they do not. That is, the voice-job rewards association (via attributions of employee proactivity) inadvertently becomes weaker when voice solicitation is higher. Figure 1 illustrates our conceptual model.

By examining this model, we make several theoretical contributions. First, we extend the voice literature by examining why and when voice is associated with job rewards (see Morrison, 2014 for a review). In general, the beneficial effects of voice typically tend to emerge only over time, as it takes much deliberation and effort to resolve employees' concerns and implement their ideas (Satterstrom et al., 2021; Sherf et al., 2019). Thus, managers might not always be able to reward voice by directly evaluating the tangible benefits that voice has brought to the workplace. We propose that voice instead allows managers to draw inferences about the underlying proactivity of employees, which can impact how they reward their employees. Moreover, given that trait inferences are impacted by situational facilitators that are discernable to observers (Ross, 1977), we note that managers who solicit voice can, ironically, discount the proactivity of employees who do speak up and reward their voice to a lesser extent than it might deserve. Thus, 
we highlight a new explanation for why voice can be associated with job rewards (proactivity attributions), as well as the conditions under which such an (indirect) association weakens (higher voice solicitation). In this process, we unravel a potentially important explanation for the variability in managerial responses to voice (see Chamberlin et al., 2017).

Second, we contribute to the literature on proactivity. Scholars have long classified voice as a proactive behavior (e.g., Parker \& Collins, 2010) given that it is characterized by a forwardlooking vision (as employees need to envisage an ideal state of affairs in the workplace before speaking up) and change-orientation (as expressions of ideas or concerns involve an implicit or explicit challenge to the status quo as well as a direct push for change) (e.g., Liang et al., 2012; Morrison, 2014). We make a case that, although putatively proactive behaviors such as voice do possess these characteristics, they might be perceived as proactive to a greater or lesser degree by different managers and, importantly, that such perceptions can impact the extent to which those behaviors are rewarded. In doing so, we underscore the need for proactivity research to examine how managers judge proactivity in the acts of their employees and the downstream consequences of such judgments on the employees.

Third, we contribute to the leadership literature by putting forth the novel proposition that voice solicitation can inadvertently induce biases in how managers evaluate employee behaviors and prevent managers from properly visualizing a connection between voice and desirable traits such as proactivity. Prior research has noted that under-appreciation of valued employee attributes typically only occurs in the context of control-oriented leader behaviors, such as close supervision or electronic monitoring (e.g., Miller et al., 2005; Strickland, 1958). We extend that research by seeking to show that such discounting can also surprisingly occur in the context of positive leader behaviors such as voice solicitation. 


\section{Theory and Hypotheses}

Employees are often the first to encounter issues in day-to-day operations and thus have access to unique information that can be critical for improving work processes (Edmondson, 2003). Moreover, they possess intimate task knowledge that can help them develop solutions to work problems. By speaking up with their ideas or concerns to managers, employees can thus alter the status quo in the workplace for the better and align it more closely with what they believe to be an ideal state. Hence, through voice, employees can help correct work inefficiencies, increase process- and product innovation, and enhance productivity (Detert et al., 2013; Lam \& Mayer, 2014; Li et al., 2017; MacKenzie et al., 2011; Sherf et al., 2018). By the same token, employees' voice can also help their managers. Even the most competent managers can make mistakes, and voice can help them quickly identify and rectify problematic work decisions and strategies (Edmondson, 2003). Not surprisingly, voice from below even allows managers to improve their own performance (Li \& Tangirala, 2021a).

Given such benefits, it is potentially important for managers to reinforce voice by properly rewarding it (see Li \& Tangirala, 2021b). However, managers often vary in how they respond to voice (Burris, 2012; Fast et al., 2014; Sherf et al., 2019). To understand when and why managers favorably reward voice, we propose that it is critical to unpack the signals employees convey to managers by speaking up. We make a case that if managers indeed reward employees for their voice, it is because the behavior can signal that employees possess certain underlying positive traits. In general, voice is a conspicuous behavior as it represents a challenge to the status quo and an often public escalation of issues to managers (Isaakyan et al., 2020). Managers are particularly likely to draw dispositional inferences about employees from such behaviors that stand out (Green \& Mitchell, 1979). Drawing on theories of dispositional 
attribution (e.g., Jones \& David, 1965), we thus highlight that voice is associated with job rewards because it allows managers to infer that their employees possess a highly desirable trait in today's organizations: Proactivity (Grant \& Ashford, 2008).

\section{Voice and Managerial Attributions of Proactivity}

Theories of dispositional attribution posit that when managers observe a certain behavior from their employees, they use that behavior as information from which to infer traits of the employees (Green \& Mitchell, 1979; Jones \& Davis, 1965). That is, managers can act as "intuitive psychologists" and make lay attempts to understand the causal determinants of their employees' behaviors (e.g., whether the employee is driven to get along with others or to make a difference in the world; Ross, 1977). A key principle in these theories is the correspondence principle, which states that when there is correspondence between the observed behavior of an actor and the trait characteristic that is prototypically associated with such behavior, the actor is classified as possessing that (corresponding) trait (Jones \& Davis, 1965). For instance, when an observer sees an actor smiling, waving, and saying hello in a friendly manner, the observer is likely to attribute the behavior to a corresponding trait of the actor, such as agreeableness.

Building on this idea, we propose that when managers observe higher levels of voice from their employees, they likely infer that the employees possess proactivity - a trait with which voice is prototypically associated. Proactivity refers to the extent to which individuals are change-oriented and demonstrate foresight (Bindl \& Parker, 2010; Crant, 2000; Grant \& Ashford, 2008; Parker \& Collins, 2010). That is, proactive employees are those who are seen to strive toward changing the work environment in a meaningful way (e.g., introducing or championing change in work practices) (Grant \& Ashford, 2008). Proactive employees are also perceived as possessing the foresight or prescience to visualize and strive toward an ideal state, 
whether it be of the self (e.g., mastering in particular software) or the work environment (e.g., making the organization error-free) (Parker \& Collins, 2010).

Voice, as a behavior, showcases these prototypical features of proactivity as a trait. First, voice signals employees' change-orientation. When speaking up, employees bring up errors that require correction or work practices that have to be modified (Edmondson, 2003; Li \& Tangirala, 2021a; Liang et al., 2012; Morrison, 2014; Van Dyne \& LePine, 1998). As such, by speaking up frequently, employees publicly show their intention to alter the status quo and their willingness to embrace change. Furthermore, when employees speak up with ideas for potential implementation or concerns that need to be addressed, it can indicate to managers that employees have constructively envisaged what they believe to be an ideal work environment, identified issues that could hinder the attainment of that ideal state, and developed solutions that could potentially tackle those issues and help build a better future (e.g., Liang et al., 2012; Whiting et al., 2012). Hence, voice also highlights employees' vision about the workplace, as well as their ability to think in a forward-looking fashion. Consequently, voice as a behavior can indicate employees' change-orientation and foresight, both of which are prototypically associated with the trait of proactivity. Given such a correspondence between voice as the observed behavior and proactivity as the underlying attribute, we propose that, in general, when managers observe higher levels of voice from an employee, they will likely infer that the employee possesses innate proactivity.

Hypothesis 1: Employee voice is positively related to managerial attributions of employee proactivity.

\section{The Moderating Role of Managerial Voice Solicitation}

In addition to the correspondence principle, theories of dispositional attribution note that 
trait inferences are also governed by the discounting principle (Green \& Mitchell, 1979; Ross, 1977; Trope, 1986). The discounting principle holds that the degree to which a behavior is attributed to an actor's innate trait is weakened when situational factors highly visible to an observer are believed to have contributed to the behavior (Reeder \& Brewer, 1979). Together with the correspondence principle, the discounting principle is "the centerpiece of general models of dispositional inference" (Reeder et al., 2004, p. 531). These two principles are considered inseparable pillars to dispositional inferences because, when judging an actor's behavior, observers naturally tend to attribute its cause to two main sources: The actor and the situation (Gilbert, 1998; Kelley, 1973). The correspondence principle allows the observer to find the cause of the behavior from factors internal to the actor, whereas the discounting principle lets the observer take into account the influence of situational inducements.

Applying the discounting principle to the context of voice, we propose that voice solicitation, a situational facilitator of voice that is cognitively readily accessible to managers, moderates the relationship between employee voice and managerial attributions of employee proactivity. Voice solicitation ${ }^{1}$ represents two highly intertwined managerial behaviors: Actively asking for and listening to employees' work input. By asking, managers can seek to open a direct channel of communication with the employees and signal that voice is welcome (Edmondson, 2003; Fast et al., 2014). At the same time, by taking a listening posture, managers can make employees feel that they have the managers' full attention and that their input will be heeded (Tangirala \& Ramanujam, 2012). For this conceptualization, the research on voice solicitation borrows from the broader communication literature that has noted that both asking and listening

\footnotetext{
${ }^{1}$ Voice literature has used the terms "voice solicitation" and "voice consultation" interchangeably and has drawn from the same scholarly sources to develop arguments for their effects (e.g., Sherf et al., 2019). Following that tradition, we do not distinguish between these terms. We use the term voice solicitation as it is more widely used.
} 
need to necessarily occur in tandem for complete conversational episodes to unfold (Hagie \& Dickson, 2004; Schein, 2013; Van Quaquebeke \& Felps, 2018). For instance, Van Quaquebeke and Felps (2018, p. 9), in their discussion of how managers can best structure "respectful inquiry" episodes that allow employees to open up and be candid in everyday conversations at work, note that, "following a question, verbal and non-verbal signals of listening reflect whether the leader is interested in the response... it is the signal of alertness and responsiveness that is crucial for the conversation as these perceived listening cues indicate to the speaker whether what they have to say is valuable and worth remembering." Furthermore, voice solicitation is viewed as a behavior that is dyadically targeted at individual employees rather than groups as a whole, because managers can seek more voice from some employees over others, depending on the task needs (Tangirala \& Ramanujam, 2012; see also Vroom \& Jago, 1988).

According to the discounting principle, when a situational facilitator directly connected to behavior is salient, observers become especially less likely to attribute the behavior to the actor's internal traits (Reeder et al., 2004; Ross \& Nisbett, 1991). For this reason, voice solicitation is uniquely pertinent as a situational inducement that can lead to a discounting effect on the voiceproactivity attribution relationship. For instance, other leadership behaviors such as transformational leadership, which appeals to ideals and provides a vision for the future to inspire employees to adopt innovative ways of thinking and acting (Bass \& Avolio, 1994), and ethical leadership, which emphasizes ethical values and models ethical conduct at work (Brown \& Treviño, 2006), can also be considered facilitators of voice (Avey et al., 2012; Liu et al., 2010). However, these leadership behaviors are designed to deliver a much broader range of outcomes beyond voice, such as job performance, creativity, and general citizenship (e.g., Piccolo \& Colquitt, 2006). By contrast, voice solicitation is specifically targeted at encouraging 
voice. Voice solicitation is also a more immediate situational inducement than leader attributes such as manager openness (Ashford et al., 1998) and supervisory responsiveness (Janssen \& Gao, 2015), both of which deal with the extent to which managers are perceived by employees to give fair consideration to ideas or concerns and take actions to address them. These leader attributes place emphasis on how managers would handle and treat voice once it is expressed (e.g., implementing ideas); hence they represent employees' evaluations of how their managers might act after they speak up. By contrast, voice solicitation seeks to persuade employees to speak up in the first place (Tangirala \& Ramanujam, 2012). Thus, as per the discounting principle, voice solicitation is a more direct and proximal situational inducement that can particularly weaken the association of voice with trait attributions.

In general, observers are said to be motivated to understand, using lay psychology, causal forces behind the actions of others (Green \& Mitchell, 1979; Ross, 1977). In particular, observers are said to have a tendency to attribute behavior to internal causes (traits) as it is cognitively simpler to do so rather than effortfully trying to account for a multitude of external reasons for the behavior (Gilbert \& Malone, 1995; Jones \& Davis, 1965). However, per the discounting principle, this typical tendency to attribute a behavior to a trait is suppressed when observers are able to swiftly visualize situational factors that can serve as plausible external sources of inducement for the behavior (Trope, 1986; Trope et al., 1988). Given that voice solicitation is a behavior that is (a) directly and explicitly targeted toward encouraging voice, and (b) one that managers have themselves engaged in (Fast et al., 2014; Sherf et al., 2019; Tangirala \& Ramanujam, 2012), from the perspective of managers, it can be easily construed as the most salient external inducement for any observed employee voice. According to the discounting principle, managers should thus adjust their instinctive tendency to attribute employee voice to 
the corresponding internal trait of proactivity by subtracting the presumed effect of their own solicitation on such voice (Gilbert et al., 1988; Trope, 1986). That is, managers who engage in greater voice solicitation become less likely to attribute higher levels of voice from employees to their innate proactivity. Hence, the association between voice and proactivity attributions should be weakened in the presence of voice solicitation. This can potentially be unfortunate, as although managers can "open the door" for employee input by soliciting voice (e.g., Tangirala \& Ramanujam, 2012; cf., Detert \& Burris, 2007), high levels of speaking up still require substantial initiative on employees' part to identify and prioritize issues to speak up about, develop solutions to fix those issues, and pick the right time and place to raise them for sufficient impact (e.g., Li \& Tangirala, 2021a). Putting these arguments together, we propose:

Hypothesis 2: Managerial voice solicitation moderates the relationship between employee voice and managerial attributions of employee proactivity, such that the relationship is less positive when managerial voice solicitation is higher.

\section{The Indirect Effects of Voice on Job Rewards}

Dispositional attributions impact how managers reward employees (Green \& Mitchell, 1979). Granting job rewards, in the form of salary increases, promotions, or high-profile projects, requires the devotion of scarce and valuable organizational resources (e.g., Gomez-Mejia \& Wiseman, 1997). Hence, managers often treat job rewards as an investment in employees and hope that it pays off well into the future (Pulakos et al., 2019). This implies that, when rewarding employees, managers seek to not only understand whether employees are currently behaving in a desirable manner but also project whether they would continue to do so in the future (Johnson et al., 2002). Because employees' traits are seen to reflect their current as well as future behavioral tendencies (Green \& Mitchell, 1979), dispositional attributions can critically impact job rewards 
that managers bestow on employees.

Building on these works, we propose that managers' attributions of proactivity will be positively associated with employees' job rewards. Proactivity is a highly desired characteristic in the workplace. To begin with, proactivity signifies that employees have a change-orientation, which is believed to be useful as employees need to constantly embrace innovation and transformation in today's highly dynamic work environments (Grant \& Ashford, 2008; Griffin et al., 2007; Parker et al., 2006). Moreover, proactivity indicates that employees hold a forwardlooking vision, which embodies their independent thinking and minimal reliance on others for help (Bateman \& Organ, 1983; Frese \& Fay, 2001). Hence, when deciding to invest in employees by, for instance, giving them bonuses or greater responsibilities through promotions and highprofile projects, managers are likely to consider whether those employees are inclined to behave in a proactive manner, now as well as in the future (see Green \& Mitchell, 1979). Attributions about employees' inherent proactivity can thus impact managers' job rewards decisions. Indeed, prior research has found that employees who are seen as proactive by managers tend to be more favorably evaluated at work (e.g., Grant et al., 2009).

Given that voice is likely positively associated with managers' proactivity attributions, we make a case that voice is also (indirectly) positively related to job rewards via such attributions. Moreover, as the effects of voice on managerial attributions of employee proactivity are likely conditional on managers' voice solicitation, the relationship between employee voice and job rewards should also be (indirectly) impacted by such voice solicitation. That is, managers who have engaged in greater voice solicitation may become less likely to connect high levels of voice with the innate proactivity of employees. Such an adjusted inference about employee proactivity will potentially carry over to reduce the job rewards granted to employees 
who speak up, thereby weakening the (indirect) positive association between voice and job rewards. Thus, we present the following set of integrative hypotheses:

Hypothesis 3: Employee voice is indirectly (via managerial attributions of employee proactivity) related to employee job rewards.

Hypothesis 4: Managerial voice solicitation moderates the positive indirect effect of employee voice on employee job rewards (via managerial attributions of employee proactivity) such that the indirect effect is less positive when managerial voice solicitation is higher.

Insert Figure 1 about here

\section{Overview of Studies}

We examined our theory in a set of 2 studies with complementary designs. Study 1 was a pre-registered between-subjects experiment that used a realistic vignette design and an online panel of U.S.-based working adults. Study 2 was designed to replicate results from Study 1 using multisource field survey data from a global technology company in the oil and gas industry with offices in India.

\section{Transparency and Openness}

We describe our sampling plan, all data exclusions (if any), manipulations, and measures, and we adhered to the Journal of Applied Psychology methodological checklist. All data, analysis codes, and materials are available on a dedicated Open Science Framework (OSF) webpage (https://bit.ly/3hYPzKM). Data were analyzed using Mplus version 8.6 (Muthén \& Muthén, 2017). All aspects of Study 1, such as hypotheses, design, and analysis, were pre-registered (https://aspredicted.org/hj8q9.pdf). Study 2's design and its analysis were not pre-registered. 


\section{Study 1}

\section{Sample and Procedures}

Study 1 was approved by the University of Maryland, College Park Institutional Review Board (IRB) (Protocol \# 1444951: Workplace Idea Solicitation). We employed a vignette-based experimental design to examine our theoretical model. A well-designed vignette can allow participants to immerse themselves in the given situation and credibly report how they would behave and make decisions in that situation (Aguinis \& Bradley, 2014). To enhance transparency as well as the scientific rigor of our study, we pre-registered all elements of the study, including hypotheses, study design, measure and items, exclusion criteria, and analysis plan, on AsPredicted.org (see pre-registration document at: https://aspredicted.org/hj8q9.pdf). The full text of our scenario, as well as all measures and items used, are available in Online Appendix A (https://bit.ly/3hYPzKM).

Six hundred and one working adults in the United States were recruited to participate in an online study through Prolific, an online platform for scientific studies (Palan \& Schitter, 2018). All recruited participants completed the study, and none submitted a duplicate response. As per our pre-registered plan, we excluded 9 participants who missed attention checks. We had a final sample of 592 participants (369 females, 209 males, and 14 identified as "Other", $M_{\text {age }}=$ 29.60, $S D_{\text {age }}=10.75$ ). Our sample was $70.1 \%$ White, $9.3 \%$ Black or African American, $8.6 \%$ Hispanic or Latino, 7.4\% Asian, $0.8 \%$ Native Hawaiian or Pacific Islander, $0.8 \%$ Native American or Alaska Native, and 2.9\% identified as “Other”. A majority of participants held a Bachelor's degree or higher (52\%) and had more than 3 years of work experience $(72.7 \%)$.

Participants were randomly assigned to 4 conditions in a 2 (employee voice: high vs. low) X 2 (manager voice solicitation: high vs. low) between-subjects design. Participants read a 
vignette that asked them to take on the role of Product Manager at a mobile game and app development company called MobiTek. The vignette informed them that MobiTek was facing multiple challenges, such as customer complaints about software crashes, coordination problems, and slow innovation relative to competitors.

Voice solicitation manipulation. In the high voice solicitation condition $(n=298)$, participants were told that, to tackle the problems, they asked Alex, an employee of theirs, for his ideas and concerns while explicitly taking on a listening posture. This manipulation was closely in line with our conceptual definition of voice solicitation; not only was it designed as a dyadic behavior (focused on an individual employee), but it also involved asking for as well as listening to employee input (Tangirala \& Ramanujam, 2012). They specifically read:

You specifically asked Alex for his opinions on the current challenges and his ideas about what can be changed in MobiTek. In meetings and one-on-ones, you encouraged Alex to share suggestions and concerns with you. You let Alex know that you would listen to any of his concerns and viewpoints carefully, even if they are different from your own. On the whole, you explicitly let Alex know several times that Alex can provide his ideas, opinions, and reactions on any major issues affecting MobiTek.

In the low voice solicitation condition $(n=294)^{2}$, participants were told that, to tackle the problems, they had engaged in various managerial tasks to solve operational problems and address business opportunities, such as analyzing data and monitoring software quality. They were also informed that they performed a managerial role vis-à-vis Alex, such that they made Alex gather data from the company's database and summarize it in a report. Participants further read that in doing so, they did not explicitly ask for or seek to listen to Alex's ideas, opinions, or reactions. They specifically read:

You have decided to look into some user statistics and data analysis to address these challenges. You have made Alex gather user traffic and customer satisfaction data from the company's database and summarize the data in a report format. You read the data report and analyzed the

\footnotetext{
${ }^{2}$ For a more conservative comparison, we conducted a pre-registered Supplemental Study in which we substituted the low voice solicitation condition with a neutral condition where voice solicitation was not mentioned at all. We replicated support for all hypotheses. Full details are available in Online Appendix B (https://bit.ly/3hYPzKM).
} 
data patterns to spot issues with the apps and games. On the whole, you have tried to solve operational problems and address business opportunities of MobiTek. In doing so, you didn't explicitly ask Alex to share his ideas, opinions, or reactions that you could listen to.

Employee voice manipulation. All participants then read that they had routine one-onones with each of their employees. In the high voice condition $(n=296)$, participants read that during the one-on-one, Alex raised a suggestion about MobiTek's recent challenges. Alex said that current issues with the apps were rooted in the fact that newly hired employees were not sufficiently trained for the job, and he suggested investing in a 4-week training program for new hires to help MobiTek's current situation with the app quality as well as new idea development. In the low voice condition $(n=296)$, participants read that during the one-on-one, although Alex shared task-relevant information, he did not raise any of his own ideas or concerns about MobiTek's recent challenges. In order to ensure that we manipulated only voice and not task performance, in both conditions, the vignette explicitly mentioned that Alex had been working in the organization for 2 years and was someone who generally performed well, completing assigned task duties and meeting all the requirements of the job.

\section{Measures}

\section{Attributions of employee proactivity and employee job rewards. To capture}

managerial attributions of proactivity, we measured the degree to which participants perceived their employee, Alex, to be proactive, using 6 items adapted from the proactive personality scale by Bateman and Crant (1993). Sample items included "Alex is constantly on the lookout for ways to improve work practices" and "Alex is proactive at work" $(1=$ strongly disagree to $7=$ strongly agree; $\alpha=.92$ ). To capture job rewards, we asked participants to respond to 4 items from the rewards recommendation scale by Allen and Rush (1998). They indicated the extent to which they would recommend Alex for 4 types of job rewards in the company, including a "salary increase," "promotion," "high-profile project," and "public recognition" $(1=$ definitely 
not recommend to $7=$ definitely recommend; $\alpha=.92)$. To check the validity of these adapted measures, we conducted a separate study with 250 working adults in the United States via Prolific. We asked participants to rate the full original and the shortened adapted scales, keeping in mind an employee who worked with them. Results indicated that the original and the adapted scales correlated highly (job rewards: $.99, p<.01$; proactivity attributions: $.85, p<.01$ ), reassuring us that our adapted measures were reasonable stand-ins for the original measures.

\section{Results and Discussion}

All the single-level regression analyses presented below were done with Mplus version 8.6 (Muthén \& Muthén, 2017), where the experimental conditions representing the independent variables were dummy coded. The interaction term was calculated by multiplying the dummy coded independent variables and was entered at Model 3. Indirect effects were estimated using bootstrapping-based analyses (5,000 replications) (Edwards \& Lambert, 2007).

Manipulation checks. To check the efficacy of our voice solicitation manipulation, we asked participants to answer the following items: "I have actively encouraged Alex to express any thoughts or concerns he has," "I have actively asked for Alex's ideas, concerns, and suggestions," and "I have carefully listened to Alex's opinions and concerns without getting defensive" $(1=$ not at all to $7=$ to a very great extent; $\alpha=.87)$. Participants in the high voice solicitation condition scored higher $(M=6.19, S D=0.90)$ than those in the low voice solicitation condition $(M=2.90, S D=1.69 ; t(590)=29.58, p<.01)$. To check the efficacy of our voice manipulation, we asked participants to answer the following items: "Alex spoke up with his ideas and opinions to suggest changes at work," "Alex made a suggestion about how to do things more effectively at work," and "Alex raised his opinion about a way to deal with MobiTek's challenges" ( $1=$ very inaccurate to $7=$ very accurate; $\alpha=.99)$. Participants in the high voice 
condition reported higher scores $(M=6.42, S D=0.90)$ than those in the low voice condition $(M$ $=1.57, S D=1.21 ; t(590)=55.36, p<.01)$. Hence, both manipulations were effective.

Insert Table 1 and Table 2 about here

Main analysis. Table 1 reports means and standard deviations of managerial attributions of employee proactivity by condition. Table 2 presents the results of regression analyses. Supporting Hypothesis 1, employee voice was positively related to managerial attributions of employee proactivity $(b=1.79, S E=0.09, p<.01$; Table 2, Model 1). Furthermore, managerial attributions of employee proactivity were positively related to employee job rewards $(b=0.58$, $S E=0.04, p<.01$; Table 2, Model 4). Bootstrap-based analysis (5,000 replications) using Mplus version 8.6 (Muthén \& Muthén, 2017) indicated that the indirect effect of employee voice on employee job rewards via managerial attributions of employee proactivity was significant $(b=$ $1.04, S E=0.09,95 \%$ CI $[0.87,1.21])$, supporting Hypothesis 3.

There was an interaction between employee voice and voice solicitation on managerial attributions of employee proactivity $(b=-1.28, S E=0.18, p<.01$; Table 2, Model 3). Participants in the high voice solicitation condition showed a weaker tendency to attribute voice to employee's proactivity $(M=4.93, S D=1.11)$ compared to those in the low voice solicitation condition $(M=5.83, S D=0.92)($ contrast $=-0.90, p<.01$; Figure 2$)$. Within low voice condition, there was also a difference in attributions of employee proactivity between participants in the high voice solicitation condition $(M=3.78, S D=1.14)$ and the low voice solicitation condition $(M=3.39, S D=1.18)$ but to a smaller degree (contrast $=0.38, p<.01)$. Moreover, simple slope analyses indicated that under the high voice solicitation condition, the relationship between voice and attributions of proactivity became weaker $(b=1.16, S E=0.13, p<.01)$, as compared to that 
under the low voice solicitation condition $(b=2.44, S E=0.13, p<.01)$. Thus, overall, results indicated support for Hypothesis 2.

We predicted that the positive indirect effect of voice on job rewards (via attributions of proactivity) would be attenuated under high voice solicitation (Hypothesis 4). Consistent with this prediction, bootstrap-based analysis (5,000 replications) indicated that the positive indirect effect of voice on rewards via managerial attributions of proactivity was attenuated under the high voice solicitation condition $(b=0.67, S E=0.10,95 \% \mathrm{CI}[0.48,0.86])$ as compared to the low voice solicitation condition $(b=1.42, S E=0.11,95 \%$ CI $[1.20,1.63])$. The difference between the two indirect effects was significant $(b=-0.75, S E=0.11,95 \% \mathrm{CI}[-0.96,-0.54])$. Thus, Hypothesis 4 was also supported.

Insert Figure 2 about here

Robustness checks. First, as pre-registered, to examine the possibility that our voice manipulation might have affected participants' perceptions of the putative employee's performance, we included a 3-item perceived performance manipulation check, adapted from the task performance measure by Williams and Anderson (1991) ("fulfills his job responsibilities," "performs his assigned duties," "meets his job requirements"; $1=$ very inaccurate to $7=$ very accurate; $\alpha=.96)$. Participants in the high voice condition reported slightly higher performance scores $(M=6.56, S D=0.72)$ than those in the low voice condition $(M=6.20, S D=1.10 ; t(590)$ $=4.78, p<.01$ ), which indicates that there might be a small spillover effect, such that employees who spoke up were seen as better performers. However, this difference between the two voice conditions in perceived performance (difference: 0.36 on a 1-7 Likert scale) was far smaller than that in our voice manipulation check measure (difference: 4.85 on a 1-7 Likert scale), suggesting 
that any spillover on perceived performance was not very strong. To rule out the possibility that perceived employee performance drove our results, we retested our regression models controlling for the perceived performance measure. Our results did not change with the inclusion of this control, indicating that our results were robust to any spillover effects that the voice manipulation had on perceived employee performance.

Second, prior research has noted that voice can constitute a threat to managers' ego and sense of authority when it is challenging to the status quo (which is how we manipulated voice in our scenario) and loyalty to the organization when it is supportive and not change-oriented (Burris, 2012). Given that perceptions of threat and loyalty about employees can be associated with job rewards granted by managers, we pre-registered to measure these alternative explanations and establish the incremental validity of proactivity attributions on job rewards. We measured threat with 3 items (e.g., "How likely is it that you will lose status in the organization by using ideas from Alex?"; $1=$ not at all to $7=$ to a very great extent; $\alpha=.88$ ) and loyalty with 3 items (e.g., "Alex is very concerned about the organization's welfare"; 1 = strongly disagree to $7=$ strongly agree; $\alpha=.82$ ) (Burris, 2012). Results indicated that there was no interaction of voice and voice solicitation on threat $(b=-0.11, S E=0.20, p=.58)$ and loyalty $(b=0.01, S E=$ $0.16, p=.97)$. Moreover, controlling for threat and loyalty, all our hypotheses were supported, indicating that proactivity attributions continued to be a significant mechanism beyond the alternative explanations of threat and loyalty.

Third, managers' attributes can also influence their evaluations of voice. For instance, managers with low self-efficacy who possess a fragile sense of ego are likely to show an aversion to voice (Fast et al., 2014). Similarly, extraverted managers who tend to be more dominant in social interactions can also show less receptivity to voice (Grant et al., 2011). To rule out such 
manager attributes as alternative explanations for our results, following our pre-registration, we measured participants' general self-efficacy using 8 items (e.g., "In general, I think that I can obtain outcomes that are important to me"; $1=$ strongly disagree to $7=$ strongly agree; $\alpha=.93$ ) (Chen et al., 2001) and extraversion using Goldberg's (1992) 5-item adjective scale (e.g., “assertive", "talkative", "bold"; $1=$ very inaccurate to $7=$ very accurate; $\alpha=.78$ ). Our results did not change controlling for self-efficacy or extraversion. Moreover, there was no significant three-way interaction between voice, voice solicitation, and self-efficacy $(b=0.11, S E=0.19, p$ $=.56)$ or extraversion $(b=0.07, S E=0.15, p=.65)$. This indicated that our results were not influenced by nor were conditional to these managerial attributes.

Discussion. Study 1 supported our theory: Voice led to higher proactivity attributions (Hypothesis 1), which, in turn, led to greater job rewards (Hypothesis 3). Importantly, when managers solicited voice, the relationship between voice and proactivity attributions became weaker (Hypothesis 2). The indirect relationship between voice and job rewards (via proactivity attributions) also became weaker under high voice solicitation (Hypothesis 4). These results remained robust to controlling for perceived employee performance, managerial reports of threat from and loyalty of the employee, and manager's self-efficacy and extraversion. Although Study 1, owing to experimental design, allowed us to infer causality, it did not provide strong external validity. To address this issue, we conducted Study 2, where we collected multisource survey data from employees and managers in a global technology company in India.

\section{Study 2}

\section{Sample and Procedures}

Study 2 was approved by the University of Maryland, College Park IRB (Protocol \# 1387926: Voice_MultipleOrgs_FieldSurvey) and was a part of a broader data collection effort. 
We collected multisource survey data from employees and managers at the India branch of a global S\&P 500 technology company in the oil and gas industry. We invited 486 employees to participate. Our final sample comprised 385 employees (79.2\% response rate) in 30 groups, managed by 27 managers (96.4\% response rate) who had matching employee and manager reports. We did not omit any other cases, and there was no missing data on our key variables from these 385 employees. Although there were two cases in which the same manager supervised 2 to 3 groups, we counted them as separate groups (i.e., 5 separate groups) as the nature of work and day-to-day operations of each group was distinct, according to our pre-survey interview with the Human Resources (HR) representative. Group size ranged from 3 to 40 ( $M_{\text {size }}$ $=12.83, S D_{\text {size }}=9.39$ ). The race or ethnicity information was not collected as it did not vary in the study context. Due to a gender imbalance in the company for technical positions, $86 \%$ of employees were male. The mean age of the employees was 29.52 years. A majority of them held a Bachelor's degree or higher (95.6\%) and had organizational tenure of 5 years or less $(85.5 \%)$.

We sought to select our survey sources in a manner that would most appropriately align with our conceptual model. We posited that managers, who observe employees speaking up, would ascribe proactivity to those employees and thus proceed to reward them. That is, managers are the ones to recognize employees' voice and make proactivity attributions as well as subsequent reward allocation decisions. Hence, we asked managers to report employee voice, attributions of employee proactivity, and the allocation of job rewards to employees. Given that there is usually a gap between the levels of voice recognized by managers and those self-reported by employees (e.g., Burris et al., 2013; Howell et al., 2015), this approach allowed us to avoid any noise associated with self-rated voice. To reduce potential concerns that manager reports were all collected at the same time, we also gathered supplementary data from managers on job 
rewards for a subset of employees one year after the initial data collection, in order to demonstrate that the effects of voice (via proactivity attributions) on job rewards held even with manager-reported data separated in time by one year. Moreover, we measured our moderator, managerial voice solicitation, using employee reports.

\section{Measures}

Employee voice. Managers rated the extent to which they observed voice from each of their employees using 3 items adapted from the constructive voice scale (Maynes \& Podsakoff, 2014). Prior studies in the voice literature have demonstrated that 3-item scales (either self- or supervisor-rated) can be sufficient to effectively capture employee voice behavior (e.g., Detert \& Burris, 2007; McClean et al., 2013). Items were "This employee makes suggestions about how to do things in new or more effective ways at work," "This employee suggests changes to work projects in order to do them better," and "This employee proposes ideas for new or more effective work methods" ( $1=$ never to $5=$ frequently; $\alpha=.93)$.

Managerial attributions of employee proactivity. We used a 3-item measure adapted from the proactive personality scale by Bateman and Crant (1993). Managers rated the extent to which they perceived each of their employees to be proactive at work. Items were "This employee tries to make a difference at work even when no one asks," "This employee takes initiative at work independently," and "This employee contributes to the team without any encouragement" and $(1=$ strongly disagree to $5=$ strongly agree; $\alpha=.89){ }^{3}$

\footnotetext{
${ }^{3}$ We used shortened scales for employee voice and proactivity attributions to reduce the cognitive load on managers, each of whom had to rate multiple employees. Prior to survey administration, we circulated the items to informed HR managers in the company to ensure that we picked the most contextually appropriate ones. To check that the validity of our measures was not compromised, we ran a separate online study with 249 working adults in the United States recruited via Prolific. We provided participants with the full and the shortened versions of the scales and asked them to rate those scales keeping in mind an employee who worked with them. Results indicated that the full and the shortened scales correlated highly (voice: .98, $p<.01$; proactivity attributions: .82, $p<.01$ ). This reassured us that our shortened measures were reasonable stand-ins for the full measures.
} 
Managerial voice solicitation. To capture manager's voice solicitation, we used the 3item manager consultation scale from the short-form of the Managerial Practices Survey (MPS; Kim \& Yukl, 1995), following prior voice research (Tangirala \& Ramanujam, 2012). In consonance with our conceptualization of voice solicitation as a dyadic leader behavior, each employee rated their manager on the following sample items: "My manager encourages me to express any concerns or doubts that I may have about a proposal under consideration," and "My manager listens carefully to any concerns that I express about his/her plans without getting defensive" ( 1 = strongly disagree to $5=$ strongly agree; $\alpha=.92)$.

To examine that this measure mapped on to our definition of voice solicitation and to ensure that it did not inadvertently conflate voice solicitation with other closely-related leader constructs, namely managerial openness (Detert \& Burris, 2007) and supervisory responsiveness (Janssen \& Gao, 2015), we conducted a separate content validation study (Colquitt et al., 2019; Hinkin \& Tracey, 1999). Full details of the study are available in Online Appendix C (https://bit.ly/3hYPzKM). We recruited 250 U.S.-based working adults via Amazon’s Turk Prime. For transparency, we pre-registered all our measures, items, and analysis: https://aspredicted.org/aj39m.pdf. Participants were presented with the definitions of voice solicitation, managerial openness, and supervisory responsiveness, as well as the corresponding items, and asked to rate how good of a job each item did in matching the construct's definition (1 $=$ extremely bad to $7=$ extremely good). Our 3-item scale showed good correspondence with the definition of voice solicitation (Hinkin Tracey correspondence index $(h t c)=0.84$ ) and strong distinctiveness from manager openness (Hinkin Tracey distinctiveness index $(h t d)=0.33$ ) and supervisory responsiveness $(h t d=0.33)$. Analysis of variance comparisons showed that all of our 3 items were a significantly better match to the definition of voice solicitation versus other 
constructs $(p$ 's $<.01)$. This strengthened our confidence in the uniqueness of voice solicitation as a construct, as well as in our survey measure.

Employee job rewards. We used the same 4 items from the reward recommendations scale by Allen and Rush (1998) as Study 1. Consistent with Study 1, managers rated the extent to which they would recommend each of their employees for 4 different types of job rewards, including "salary increase," "promotion," "high-profile project," and "public recognition" $(1=$ would definitely not recommend to $5=$ would recommend without reservation; $\alpha=.87$ ).

\section{Analytical Approach}

Our phenomenon of interest lies at the employee level of analysis. In our sample, however, employees (Level 1) were nested within their managers/groups (Level 2), violating the independence of observations assumption. To account for this nesting, we used multilevel

analyses with TWOLEVEL RANDOM option in Mplus version 8.6 (Muthén \& Muthén, 2017). We employed a random intercept model and allowed the intercepts at Level 2 to freely vary to allow for the separate estimation of variances at the individual and group levels. All our substantive independent variables were modeled at Level 1 and group-mean centered to prevent conflation of individual and group-level effects (Preacher et al., 2010). We computed pseudo- $R^{2}$ values by examining the Level 1 variances explained in the dependent variable by the predictors. The interaction term was calculated by multiplying the group-mean centered scores of voice and voice solicitation and was entered at Model 3. Confidence intervals for indirect effects were calculated using Monte Carlo-based simulation (20,000 repetitions; Selig \& Preacher, 2008).

\section{Results and Discussion}

Confirmatory factor analysis. We conducted confirmatory factor analysis to establish the discriminant validity of our measures. The measurement model, in which voice, managerial 
solicitation of voice, attributions of proactivity, and job rewards loaded on separate factors, fit the data well $\left(\chi^{2}(59)=145.03, p<.01, \mathrm{CFI}=.98, \mathrm{SRMR}=.03, \mathrm{RMSEA}=.06\right)$. Wald test of parameter constraints indicated that this measurement model was a better fit to the data compared to models that set the correlations of the following manager-rated measures to 1: Voice and attributions of proactivity $\left(\Delta \chi^{2}(\Delta d f=1)=70.41, p<.01\right)$, voice and job rewards $\left(\Delta \chi^{2}(\Delta d f=\right.$ $1)=80.01, p<.01)$, and attributions of proactivity and job rewards $\left(\Delta \chi^{2}(\Delta d f=1)=57.50, p\right.$ $<.01)$. These results indicated that our measures were distinct from each other. ${ }^{4}$

Insert Table 3 and Table 4 about here

Main analyses. Table 3 reports descriptive statistics and correlations among key variables, and Table 4 displays the results of regression analyses. Results indicated that voice was positively related to attributions of proactivity $(b=0.70, S E=0.03, p<.01$; Table 4 , Model 1), supporting Hypothesis 1. Further, attributions of proactivity were positively associated with job rewards $(b=0.51, S E=0.05, p<.01$; Table 4, Model 4). The indirect effects of voice via attributions of proactivity on job rewards was also significant $(b=0.36, S E=0.04,95 \% \mathrm{CI}$ $[0.29,0.43])$, supporting Hypothesis 3.

There was also a significant interaction between voice and voice solicitation on attributions of proactivity $(b=-0.09, S E=0.04, p<.05$; Table 4, Model 3). As shown in Figure 3 , the effect of voice on attributions of proactivity became less positive when voice solicitation was higher $(+1 \mathrm{SD} ; b=0.58, S E=0.05, p<.01)$ as compared to when it was lower $(-1 \mathrm{SD} ; b=$

\footnotetext{
${ }^{4}$ We had a relatively small number of clusters (i.e., managers/groups) compared to the number of parameters (Mok, 1995). Hence, we could not conduct a multilevel confirmatory factor analyses (MCFA) on our full measurement model (Dyer et al., 2005). Following previous research (e.g., Wang et al., 2018), as a partial solution to this problem, we tested a series of one-factor MCFA models. To gain identification, for all models, we consistently fixed the residual variance of the one item to 0 at the between level. The piecemeal MCFAs indicated good validity for our measures (average $\mathrm{CFI}=.987$; average $\mathrm{SRMR}=.010$ ). All data and syntax for MCFA are available on OSF: https://bit.ly/3hYPzKM.
} 
$0.79, S E=0.05, p<.01)($ diff: $b=-0.20, S E=0.08, p<.05)$, supporting Hypothesis 2 .

Results further indicated that the indirect effects of voice on job rewards via attributions of proactivity were less positive under higher voice solicitation $(b=0.30, S E=0.04,95 \% \mathrm{CI}$ $[0.22,0.37])$ as compared to lower voice solicitation $(b=0.40, S E=0.05,95 \% \mathrm{CI}[0.31,0.48])$. The difference between the indirect effects was also significant $(b=-0.10, S E=0.04,95 \%$ CI [$0.18,-0.02])$, supporting Hypothesis 4.

Insert Figure 3 about here

Robustness checks. First, we had measured voice, proactivity attributions, and job rewards using manager reports, and the relationships amongst these variables might have been affected by single source biases. However, Harman's single-factor test indicated that the fit of a single-factor model, in which all items for these variables were loaded on one factor $\left(\chi^{2}(35)=\right.$ $552.18, p<.01, \mathrm{CFI}=.83, \mathrm{SRMR}=.07, \mathrm{RMSEA}=.20)$, was significantly worse than the threefactor model where items were loaded on each corresponding construct $\left(\chi^{2}(32)=110.33, p<.01\right.$, $\mathrm{CFI}=.97, \mathrm{SRMR}=.03, \mathrm{RMSEA}=.08)\left(\Delta \chi^{2}(\Delta d f=3)=441.85, p<.01\right)$. This provided a reasonable level of assurance that these variables did not exhibit a severe single source bias (Podsakoff et al., 2003). To further establish confidence in our results, we reached back to the company approximately a year after our original survey administration and asked managers to again provide job rewards ratings for the employees in our sample (i.e., job rewards one year later; using the same items as in the original survey; $\alpha=.86)$. We were able to obtain such data on 273 out of the original 385 employees who were still with the organization since our original survey. Analysis using this sub-sample of employees indicated that attributions of employee proactivity from the original survey predicted job rewards one year later $(b=0.29, S E=0.10, p$ 
$<.01$ ). Moreover, voice rated in the original survey had an indirect effect (via proactivity attributions) on those job rewards one year later $(b=0.20,95 \% \mathrm{CI}[0.07,0.33])$. These indirect effects were also conditional on voice solicitation (the difference at higher vs. lower voice solicitation: $b=-0.06,95 \% \mathrm{CI}[-0.13,-0.01])$. These results indicate that voice from our original survey did indeed have (conditional) indirect effects on job rewards one year later. Given that time separation, especially of a year, is likely to diminish any same source effects (Podsakoff et al., 2003), these results enhanced our confidence in our original findings.

We conceptualized, operationalized, and analyzed voice solicitation as an individual-level variable. As a robustness check, we examined our results aggregating voice solicitation to the group level; that is, voice solicitation was considered a general leader behavior within the group rather than a dyadic behavior targeted at individual employees $(\operatorname{ICC}(1)=.18$, indicating that $82 \%$ of the variation was at the individual level; $\operatorname{ICC}(2)=.75$; mean corrected $\left.r_{w g(j)}=.68\right)$. As detailed in Online Appendix D (https://bit.ly/3hYPzKM), when modeling the cross-level moderating effects of group-aggregated voice solicitation on the voice $\rightarrow$ proactivity attributions $\rightarrow$ job rewards relationship, we obtained similar results to those from our individual-level analysis, indicating that our results were robust to alternative operationalizations of voice solicitation.

Discussion. Overall, the results of Study 2 replicated our findings from Study 1 and supported our theory. Voice was positively associated with proactivity attributions, which, in turn, were related to higher job rewards (Hypotheses 1 and 3). We also found that the indirect relationship between voice and job rewards (via attributions of proactivity) became weaker when managers solicited more voice (Hypotheses 2 and 4). Supplemental analyses with a substantive subsample of our survey respondents suggested that our model remained robust when using job rewards captured one year after our original survey administration. 


\section{General Discussion}

We drew on theories of dispositional attribution (Green \& Mitchell, 1979; Jones \& Davis, 1965; Ross, 1977) to argue that managers draw inferences about employees' proactivity based on observed levels of voice and that such inferences are a key reason why managers reward employees who speak up at work. We also made a case that the tendency to attribute proactivity to employees based on their voice levels weakens when managers solicit voice from employees to a greater extent. That is, voice solicitation, a managerial behavior designed to set facilitating conditions for speaking up, can paradoxically suppress the (indirect) relationship between voice and job rewards. We established support for our theory in a set of 2 studies: (a) A pre-registered experiment with an online panel of working adults based in the United States and (b) a multisource survey-based study of a global technology company in the oil and gas industry in India. Our findings have several theoretical implications, which we discuss below.

\section{Theoretical Contributions}

Contributions to the voice literature. In recent years, the voice literature has started to recognize that to sustainably motivate voice, employees need to be properly rewarded for speaking up. For instance, in a recent field intervention (Li \& Tangirala, 2021b), scholars have demonstrated that providing adequate reward structures for voice (e.g., bonuses for expressing concerns or ideas) is an effective way of stimulating the behavior. As such, it is important to examine how managers go about rewarding employees who make the effort to speak up at work. We address this issue and contribute to voice research in two distinct ways.

First, we explicate a novel pathway (i.e., proactivity attributions) that can explain why managers reward voice. In so unpacking a key mediator of the voice-job rewards association, we extend the voice literature. A dominant focus of voice research has been on how managers deal 
with the challenge to the status quo posed by voice. Voice can be considered an implicit or explicit criticism of people in positions of power, and it is thus said to constitute a threat to managers' sense of authority and competence, which explains why managers can sometimes have less positive reactions to voice (Fast et al., 2014; Isaakyan et al., 2020). For instance, Burris (2012) highlights that voice is negatively related to performance evaluations because of the threat it presents to managers and that voice is only favorably received when it supports (rather than challenges) the status quo and thus indicates employees' loyalty to the current state of affairs. The implications of such studies have been that employees who seek positive evaluations for voice should attempt to reduce the threat they may convey by, for example, modifying the content of their voice (see also Chamberlin et al., 2017 for a related suggestion). In contrast, we show that even voice with challenging content (e.g., ideas for changing work processes or concerns about undesirable work behaviors) can be positively associated with job rewards via proactivity attributions (controlling for the effects of threat; see Study 1). Thus, we suggest that voice research should go beyond treating threat as a hurdle to getting adequate job rewards for speaking up and showcase that voice can allow for positive trait inferences and thus allow for job rewards.

Second, from a conceptual (see Morrison, 2014 for review) as well as an empirical (see Chamberlin et al., 2017 for meta-analysis) viewpoint, scholars have noted that there is likely variability in how managers respond to voice and that research should further explore when voice leads to positive consequences for employees in order to make meaningful conceptual progress. We tackle this issue by demonstrating that voice solicitation, a behavior that is intended to encourage voice, can ironically reduce managers' inclination to see proactivity in employees' speak-up behaviors and, thereby, weaken the (indirect) relationship between voice and job 
rewards. In fact, some studies have conflated managers' lack of willingness to adequately reward voice that comes their way and their disinclination to solicit voice as parts of a unitary construct of managerial "aversion to voice" (Fast et al., 2014). We not only highlight that soliciting voice is distinct from rewarding voice that emerges from employees but also note that the former can weaken managers' tendency to engage in the latter. In doing so, our theory pushes voice scholarship to examine how different elements of the voice generation process that are assumed to act in consonance with each other can sometimes work in a contradictory manner.

Contributions to the proactivity literature. We add to conversations in the research on proactivity that have noted the possibility that inferences of proactivity can be subjective (e.g., Grant \& Ashford, 2008). Voice is often classified as a proactive behavior (Parker \& Collins, 2010) because it is both forward-looking and change-orientated (Liang et al., 2012; Morrison, 2014). We point out that, although voice might have these characteristics, the proactivity that managers perceive in the behavior can vary based on their own voice solicitation levels, and that such perceptions have important implications for the employees in terms of the rewards they are able to garner for their voice. Through our research, we thus highlight that it is important for the proactivity literature to consider and examine when and to what extent managers actually attribute proactivity to their employees.

In particular, future research should examine whether the joint effects of leader behaviors and employee actions on proactivity attributions are unique to voice or generalizable to other proactive behaviors. On the one hand, voice can stand out as a behavior because it is frequently a public act and involves a direct escalation of issues to managers (Isaakyan et al., 2020). Hence, compared to other proactive employee behaviors that may be less visible to managers, such as feedback-seeking or job crafting (Ashford et al., 2003; Wrzesniewski \& Dutton, 2001), voice can 
allow for more confident inferences about employee proactivity (see Green \& Mitchell, 1979). In this context, our demonstration that managers differ in the extent to which they see proactivity in voice suggests that there are likely even greater variations in how other proactive behaviors are recognized by managers as being so. On the other hand, as voice occurs within a dyadic context as a communication act between an employee and a manager, it can potentially require cogeneration to a greater extent than other proactive behaviors (e.g., taking charge or personal initiative that are largely characterized by independent actions on the part of employees; Frese \& Fay, 2001; Morrison \& Phelps, 1999). From this perspective, voice might be more prone to discounting effects during the trait attribution processes than other proactive behaviors (see Trope, 1986). To gain deeper insight into this issue, research should systematically compare how managers view and reward different proactive behaviors and the extent to which they are subject to potential biases in managerial evaluation.

Contributions to the leadership literature. Prior research has noted that leaders are prone to discounting effects when making inferences about employees' traits from their behavior. However, this line of works has focused more on control-oriented leader behaviors, such as close supervision or monitoring. For instance, studies have shown that leaders who actively monitor or surveil employees tend to discount the innate honesty and trustworthiness of those employees who have conscientiously performed their work (Strickland, 1958; see also Miller et al., 2005 and Pfeffer et al., 1998 for discussions about related effects). We differ from these works in noting that such discounting effects can even emerge in the context of positive leader behaviors that encourage employee participation, such as voice solicitation. In demonstrating this, we highlight the need for leadership research to further examine how leaders' own actions or behaviors can influence how they respond to (and appreciate) employee behaviors and effort at 
work.

\section{Limitations and Directions for Future Research}

Our studies have several limitations. First, although our experimental study (Study 1) allows for inferences of causality, its external validity is compromised, as communication between managers and employees in real organizational settings may be embedded within more complex interpersonal dynamics than represented in the experiment. Although we sought to address this concern in the field through Study 2, the correlational nature of this study does not allow for strong conclusions about the causality. Future research can use empirical designs that combine our approaches in Studies 1 and 2, such as field experiments (Grant \& Wall, 2009), to better balance these internal and external validity concerns.

Second, we used shortened measures for some key constructs_-voice and proactivity attributions - in our field study at the request of the participating organization to keep our survey to a manageable length and to reduce cognitive load on the managers who had to rate multiple employees. Although supplementary data indicated that our shortened measures were reasonable stand-ins for longer measures available in the literature, we urge future studies to replicate our results in the field using longer measures for these constructs. Relatedly, following prior works (e.g., Tangirala \& Ramanujam, 2012), we used a 3-item measure of voice solicitation. This measure captures both asking ( 2 items) and listening ( 1 item) that together constitute the construct of voice solicitation. Further, our results held even when we operationalized voice solicitation using only the 2 items that reflected asking on the part of the manager. We however urge future studies to develop a longer and more detailed measure of voice solicitation so that any differential effects between its asking and listening components can be better unpacked.

Third, our studies presented a one-time snapshot of attributional processes and their 
outcomes. Future research can supplement these studies with a longitudinal examination of the phenomenon. Such research can further explore the longer-term consequences of the trait discounting effects found in our studies. When employees gain discounted attributions of proactivity and lesser rewards for speaking up under higher (versus lower) levels of voice solicitation, they may believe that managers are not genuinely open to employee ideas and concerns, which can damage the trust between managers and employees. Furthermore, if such a trend continues, employees may interpret it as a negative signal of their value to the organization and may even choose to leave the organization altogether. Hence, longitudinal observations can help unpack the consequences of the observed discounting pattern over longer time horizons. Similarly, studies can explore whether and how proactivity attributions change over time. For instance, people are prone to making person-related judgments from thin slices of data (Tskhay et al., 2017). Once these judgments are formed, people can be resistant to change them as such "judgments are used more frequently than they are revised" (Soenen et al., p. 800). Hence, it is possible that once proactivity attributions about employees are made, they continue to determine job rewards for long periods of time unless "phase-shifting” events occur (e.g., a highly visible act of voice in an important meeting that negates low proactivity judgment based on the employee's prior episodes of silence). Alternatively, it is also possible that proactivity attributions slowly erode over time unless they are continuously reinforced by consistent acts of voice from employees (see Burger, 1991). Research that explores such changes in proactivity attributions over time can extend our theory and highlight how prior voice behavior, combined with current voice behavior, would impact such attributions.

Finally, other factors apart from voice solicitation can impact the relationship between voice and proactivity attributions. For instance, a positive leader-member exchange (LMX) can 
enhance the voice-proactivity attributions relationship by favorably biasing managers toward their employees (Green \& Mitchell, 1979). Alternatively, although we did not find significant effects of manager traits such as extraversion or generalized self-efficacy (see robustness checks in Study 1), other traits may act as potential boundary conditions. For example, managers high on narcissism can be more prone to self-serving biases (Owens et al., 2015). Hence, they might be more likely to attribute voice to their own managerial actions (i.e., voice solicitation) rather than to the innate traits of their employees (i.e., proactivity). Thus, manager narcissism can weaken the voice-proactivity attribution link. As such, studies can extend our theory by more broadly testing the effects of other potential moderators based on the principles and findings discussed in the attribution literature (e.g., Green \& Mitchell, 1979).

\section{Managerial Implications}

Managers are the linchpins who connect employees to higher levels of leadership in organizations. By explicitly soliciting voice from employees, managers can play a critical role in facilitating the transmission of employee input up the hierarchy. At the same time, managers, as observers and direct recipients of voice, also bear the responsibility for properly rewarding employees who speak up frequently at work as a demonstration of their appreciation for employee proactivity. We find that managers who engage in voice solicitation can more weakly connect voice to the innate proactivity of employees and, thereby, become less willing to reward those employees. Managers should be cognizant of this bias and be wary that such a tendency might send contradictory signals to employees about how their voice is valued in the workplace. After all, change-orientation, forward-looking vision, and efforts underlie the act of voice irrespective of whether it emerges in the context of high or low voice solicitation. By being cognizant of this bias, managers can more successfully create work environments where 
employees candidly share their ideas and concerns, feel that their input is welcomed, and believe that their proactive effort will be properly rewarded and appreciated. 


\section{References}

Aguinis, H., \& Bradley, K. J. (2014). Best practice recommendations for designing and implementing experimental vignette methodology studies. Organizational Research Methods, 17(4), 351-371. https://doi.org/10.1177/1094428114547952

Allen, T. D., \& Rush, M. C. (1998). The effects of organizational citizenship behavior on performance judgments: a field study and a laboratory experiment. Journal of Applied Psychology, 83(2), 247-260. https://doi.org/10.1037/0021-9010.83.2.247

Ashford, S. J., Blatt, R., \& VandeWalle, D. (2003). Reflections on the looking glass: A review of research on feedback-seeking behavior in organizations. Journal of Management, 29(6), 773799. https://doi.org/10.1016/S0149-2063(03)00079-5

Ashford, S. J., Rothbard, N. P., Piderit, S. K., \& Dutton, J. E. (1998). Out on a limb: The role of context and impression management in selling gender-equity issues. Administrative Science Quarterly, 43(1), 23-57. https://doi.org/10.2307/2393590

Avey, J. B., Wernsing, T. S., \& Palanski, M. E. (2012). Exploring the process of ethical leadership: The mediating role of employee voice and psychological ownership. Journal of Business Ethics, 107(1), 21-34. https://doi.org/10.1007/s10551-012-1298-2

Bass, B. M., \& Avolio, B. J. (1994). Improving organizational effectiveness through transformational leadership. Thousand Oaks, CA: Sage.

Bateman, T. S., \& Crant, J. M. (1993). The proactive component of organizational behavior: A measure and correlates. Journal of Organizational Behavior, 14(2), 103-118. https://doi.org/10.1002/job.4030140202

Bateman, T. S., \& Organ, D. W. (1983). Job satisfaction and the good soldier: The relationship between affect and employee "citizenship". Academy of Management Journal, 26(4), 587595. https://doi.org/10.5465/255908

Bindl, U., \& Parker, S. K. (2010). Proactive work behavior: Forward-thinking and changeoriented action in organizations. In S. Zedeck (Ed.), APA handbook of industrial and organizational psychology: Vol. 2. Selecting and developing members for the organization (pp. 567-598). Washington, DC: American Psychological Association.

Brown, M. E., \& Treviño, L. K. (2006). Ethical leadership: A review and future directions. The Leadership Quarterly, 17(6), 595-616. https://doi.org/10.1016/j.leaqua.2006.10.004

Burger, J. M. (1991). Changes in attributions over time: The ephemeral fundamental attribution error. Social Cognition, 9(2), 182-193. https://doi.org/10.1521/soco.1991.9.2.182

Burris, E. R. (2012). The risks and rewards of speaking up: Managerial responses to employee voice. Academy of Management Journal, 55(4), 851-875.

https://doi.org/10.5465/amj.2010.0562

Burris, E. R., Detert, J. R., \& Romney, A. C. (2013). Speaking up vs. being heard: The disagreement around and outcomes of employee voice. Organization Science, 24(1), 22-38. https://doi.org/10.1287/orsc.1110.0732

Chamberlin, M., Newton, D. W., \& Lepine, J. A. (2017). A meta-analysis of voice and its promotive and prohibitive forms: Identification of key associations, distinctions, and future research directions. Personnel Psychology, 70(1), 11-71. https://doi.org/10.1111/peps.12185

Chen, G., Gully, S. M., \& Eden, D. (2001). Validation of a new general self-efficacy scale. Organizational Research Methods, 4(1), 62-83. https://doi.org/10.1177/109442810141004 
Colquitt, J. A., Sabey, T. B., Rodell, J. B., \& Hill, E. T. (2019). Content validation guidelines: Evaluation criteria for definitional correspondence and definitional distinctiveness. Journal of Applied Psychology, 104(10), 1243-1265. https://doi.org/10.1037/ap10000406

Crant, J. M. (2000). Proactive behavior in organizations. Journal of Management, 26(3), 435462. https://doi.org/10.1177/014920630002600304

Detert, J. R., \& Burris, E. R. (2007). Leadership behavior and employee voice: Is the door really open?. Academy of Management Journal, 50(4), 869-884. https://doi.org/10.5465/amj.2007.26279183

Detert, J. R., Burris, E. R., Harrison, D. A., \& Martin, S. R. (2013). Voice flows to and around leaders: Understanding when units are helped or hurt by employee voice. Administrative Science Quarterly, 58(4), 624-668. https://doi.org/10.1177/0001839213510151

Dyer, N. G., Hanges, P. J., \& Hall, R. J. (2005). Applying multilevel confirmatory factor analysis techniques to the study of leadership. The Leadership Quarterly, 16(1), 149-167. https://doi.org/10.1016/j.leaqua.2004.09.009

Eastman, K. K. (1994). In the eyes of the beholder: An attributional approach to ingratiation and organizational citizenship behavior. Academy of Management Journal, 37(5), 1379-1391. https://doi.org/10.5465/256678

Edmondson, A. C. (2003). Speaking up in the operating room: How team leaders promote learning in interdisciplinary action teams. Journal of Management Studies, 40(6), 1419-1452. https://doi.org/10.1111/1467-6486.00386

Edwards, J. R., \& Lambert, L. S. (2007). Methods for integrating moderation and mediation: A general analytical framework using moderated path analysis. Psychological Methods, 12(1), 1-22. https://doi.org/10.1037/1082-989X.12.1.1

Fast, N. J., Burris, E. R., \& Bartel, C. A. (2014). Managing to stay in the dark: Managerial selfefficacy, ego defensiveness, and the aversion to employee voice. Academy of Management Journal, 57(4), 1013-1034. https://doi.org/10.5465/amj.2012.0393

Frese, M., \& Fay, D. (2001). 4. Personal initiative: An active performance concept for work in the 21st century. Research in Organizational Behavior, 23, 133-187. https://doi.org/10.1016/S0191-3085(01)23005-6

Gilbert, D. T. (1998). Ordinary personology. In D. T. Gilbert, S. T. Fiske, \& G. Lindzey (Eds.), The handbook of social psychology (Vol. 2, 4th ed., pp. 89-150). Boston: McGraw-Hill.

Gilbert, D. T., \& Malone, P. S. (1995). The correspondence bias. Psychological Bulletin, 117(1), 21-38. https://doi.org/10.1037/0033-2909.117.1.21

Gilbert, D. T., Pelham, B. W., \& Krull, D. S. (1988). On cognitive busyness: When person perceivers meet persons perceived. Journal of Personality and Social Psychology, 54(5), 733-740. https://doi.org/10.1037/0022-3514.54.5.733

Goldberg, L. R. (1992). The development of markers for the Big-Five factor structure. Psychological Assessment, 4, 26-42. http://dx.doi.org/10.1037/1040-3590.4.1.26

Gomez-Mejia, L., \& Wiseman, R. M. (1997). Reframing executive compensation: An assessment and outlook. Journal of Management, 23(3), 291-374. https://doi.org/10.1016/S0149-2063(97)90035-0

Grant, A. M., \& Ashford, S. J. (2008). The dynamics of proactivity at work. Research in Organizational Behavior, 28, 3-34. https://doi.org/10.1016/j.riob.2008.04.002

Grant, A. M., Gino, F., \& Hofmann, D. A. (2011). Reversing the extraverted leadership advantage: The role of employee proactivity. Academy of Management Journal, 54(3), 528550. https://doi.org/10.5465/amj.2011.61968043 
Grant, A. M., Parker, S., \& Collins, C. (2009). Getting credit for proactive behavior: Supervisor reactions depend on what you value and how you feel. Personnel Psychology, 62(1), 31-55. https://doi.org/10.1111/j.1744-6570.2008.01128.x

Grant, A. M., \& Wall, T. D. (2009). The neglected science and art of quasi-experimentation: Why-to, when-to, and how-to advice for organizational researchers. Organizational Research Methods, 12(4), 653-686. https://doi.org/10.1177/1094428108320737

Green, S. G., \& Mitchell, T. R. (1979). Attributional processes of leaders in leader-member interactions. Organizational Behavior and Human Performance, 23(3), 429-458. https://doi.org/10.1016/0030-5073(79)90008-4

Griffin, M. A., Neal, A., \& Parker, S. K. (2007). A new model of work role performance: Positive behavior in uncertain and interdependent contexts. Academy of Management Journal, 50(2), 327-347. https://doi.org/10.5465/amj.2007.24634438

Hagie, B \& Dickson, D. (2004). Skilled interpersonal communication. New York: Routledge.

Hinkin, T. R., \& Tracey, J. B. (1999). An analysis of variance approach to content validation. Organizational Research Methods, 2(2), 175-186. https://doi.org/10.1177/109442819922004

Howard, J. A. (1985). Further appraisal of correspondent inference theory. Personality and Social Psychology Bulletin, 11(4), 467-477. https://doi.org/10.1177/0146167285114012

Howell, T. M., Harrison, D. A., Burris, E. R., \& Detert, J. R. (2015). Who gets credit for input? Demographic and structural status cues in voice recognition. Journal of Applied Psychology, 100(6), 1765-1784. https://doi.org/10.1037/apl0000025

Isaakyan, S., Sherf, E. N., Tangirala, S., \& Guenter, H. (2020). Keeping it between us: Managerial endorsement of public versus private voice. Journal of Applied Psychology. Advance online publication. https://doi.org/10.1037/apl0000816

Janssen, O., \& Gao, L. (2015). Supervisory responsiveness and employee self-perceived status and voice behavior. Journal of Management, 41(7), 1854-1872. https://doi.org/10.1177/0149206312471386

Johnson, D. E., Erez, A., Kiker, D. S., \& Motowidlo, S. J. (2002). Liking and attributions of motives as mediators of the relationships between individuals' reputations, helpful behaviors and raters' reward decisions. Journal of Applied Psychology, 87(4), 808-815. https://doi.org/10.1037/0021-9010.87.4.808

Jones, E. E., \& Davis, K. E. (1965). From acts to dispositions the attribution process in person perception. Advances in Experimental Social Psychology, 2, 219-266. https://doi.org/10.1016/S0065-2601(08)60107-0

Kelley, H. H. (1973). The processes of causal attribution. American Psychologist, 28(2), 107128. https://doi.org/10.1037/h0034225

Kerr, S. (1995). On the folly of rewarding A, while hoping for B. The Academy of Management Executive, 9, 7-14. https://doi.org/10.5465/ame.1995.9503133466

Kim, H., \& Yukl, G. (1995). Relationships of managerial effectiveness and advancement to selfreported and subordinate-reported leadership behaviors from the multiple-linkage mode. The Leadership Quarterly, 6(3), 361-377. https://doi.org/10.1016/1048-9843(95)90014-4

Lam, C. F., \& Mayer, D. M. (2014). When do employees speak up for their customers? A model of voice in a customer service context. Personnel Psychology, 67(3), 637-666. https://doi.org/10.1111/peps. 12050

Li, A. N., Liao, H., Tangirala, S., \& Firth, B. M. (2017). The content of the message matters: The differential effects of promotive and prohibitive team voice on team productivity and safety 
performance gains. Journal of Applied Psychology, 102(8), 1259-1270. https://doi.org/10.1037/ap10000215

Li, A. N., \& Tangirala, S. (2021a). How voice emerges and develops in newly formed supervisoremployee dyads. Academy of Management Journal. Advance online publication. https://doi.org/10.5465/amj.2018.0961

Li, A. N., \& Tangirala, S. (2021b). How employees' voice helps teams remain resilient in the face of exogenous change. Journal of Applied Psychology. Advance online publication. https://doi.org/10.1037/ap10000874

Liang, J., Farh, C. I., \& Farh, J. L. (2012). Psychological antecedents of promotive and prohibitive voice: A two-wave examination. Academy of Management Journal, 55(1), 71-92. https://doi.org/10.5465/amj.2010.0176

Liu, W., Zhu, R., \& Yang, Y. (2010). I warn you because I like you: Voice behavior, employee identifications, and transformational leadership. The Leadership Quarterly, 21(1), 189-202. https://doi.org/10.1016/j.leaqua.2009.10.014

MacKenzie, S. B., Podsakoff, P. M., \& Podsakoff, N. P. (2011). Challenge-oriented organizational citizenship behaviors and organizational effectiveness: Do challenge-oriented behaviors really have an impact on the organization's bottom line?. Personnel Psychology, 64(3), 559-592. https://doi.org/10.1111/j.1744-6570.2011.01219.x

Maynes, T. D., \& Podsakoff, P. M. (2014). Speaking more broadly: An examination of the nature, antecedents, and consequences of an expanded set of employee voice behaviors. Journal of Applied Psychology, 99(1), 87-112. https://doi.org/10.1037/a0034284

McClean, E. J., Burris, E. R., \& Detert, J. R. (2013). When does voice lead to exit? It depends on leadership. Academy of Management Journal, 56(2), 525-548. https://doi.org/10.5465/amj.2011.0041

Miller, D. T., Visser, P. S., \& Staub, B. D. (2005). How surveillance begets perceptions of dishonesty: the case of the counterfactual sinner. Journal of Personality and Social Psychology, 89(2), 117-128. https://doi.org/10.1037/0022-3514.89.2.117

Mok, M. (1995). Sample size requirements for 2-level designs in educational research. Multilevel Modeling Newsletter, 7,11-15.

Morrison, E. W. (2014). Employee voice and silence. Annual Review of Organizational Psychology and Organizational Behavior, 1(1), 173-197. https://doi.org/10.1146/annurev-orgpsych-031413-091328

Morrison, E. W., \& Phelps, C. C. (1999). Taking charge at work: Extrarole efforts to initiate workplace change. Academy of Management Journal, 42(4), 403-419. https://doi.org/10.5465/257011

Muthén, L. K., \& Muthén, B. (2017). Mplus user's guide: 8th edition. Los Angeles, CA: Author.

Owens, B. P., \& Hekman, D. R. (2016). How does leader humility influence team performance? Exploring the mechanisms of contagion and collective promotion focus. Academy of Management Journal, 59(3), 1088-1111. https://doi.org/10.5465/amj.2013.0660

Palan, S., \& Schitter, C. (2018). Prolific. ac - A subject pool for online experiments. Journal of Behavioral and Experimental Finance, 17, 22-27. https://doi.org/10.1016/j.jbef.2017.12.004

Parker, S. K., \& Collins, C. G. (2010). Taking stock: Integrating and differentiating multiple proactive behaviors. Journal of Management, 36(3), 633-662. https://doi.org/10.1177/0149206308321554

Parker, S. K., Williams, H. M., \& Turner, N. (2006). Modeling the antecedents of proactive behavior at work. Journal of Applied Psychology, 91(3), 636-652. 
https://doi.org/10.1037/0021-9010.91.3.636

Pfeffer, J., Cialdini, R. B., Hanna, B., \& Knopoff, K. (1998). Faith in supervision and the selfenhancement bias: Two psychological reasons why managers don't empower workers. Basic and Applied Social Psychology, 20(4), 313-321. https://doi.org/10.1207/s15324834basp2004_8

Piccolo, R. F., \& Colquitt, J. A. (2006). Transformational leadership and job behaviors: The mediating role of core job characteristics. Academy of Management Journal, 49(2), 327-340. https://doi.org/10.5465/amj.2006.20786079

Podsakoff, P. M., MacKenzie, S. B., Lee, J. Y., \& Podsakoff, N. P. (2003). Common method biases in behavioral research: a critical review of the literature and recommended remedies. Journal of Applied Psychology, 88(5), 879-903. https://doi.org/10.1037/0021-9010.88.5.879

Preacher, K. J., Zyphur, M. J., \& Zhang, Z. (2010). A general multilevel SEM framework for assessing multilevel mediation. Psychological Methods, 15(3), 209-233. https://doi.org/10.1037/a0020141

Pulakos, E. D., Mueller-Hanson, R., \& Arad, S. (2019). The evolution of performance management: Searching for value. Annual Review of Organizational Psychology and Organizational Behavior, 6, 249-271. https://doi.org/10.1146/annurev-orgpsych-012218-015009

Reeder, G. D., \& Brewer, M. B. (1979). A schematic model of dispositional attribution in interpersonal perception. Psychological Review, 86(1), 61-79. https://doi.org/10.1037/0033-295X.86.1.61

Reeder, G. D., Vonk, R., Ronk, M. J., Ham, J., \& Lawrence, M. (2004). Dispositional attribution: Multiple inferences about motive-related traits. Journal of Personality and Social Psychology, 86(4), 530-544. https://doi.org/10.1037/0022-3514.86.4.530

Ross, L. (1977). The intuitive psychologist and his shortcomings: Distortions in the attribution process. Advances in Experimental Social Psychology, 10, 173-220. https://doi.org/10.1016/S0065-2601(08)60357-3

Ross, L., \& Nisbett, R. E. (1991). The person and the situation: Perspectives of social psychology. New York: McGraw-Hill.

Satterstrom, P., Kerrissey, M., \& DiBenigno, J. (2021). The voice cultivation process: How team members can help upward voice live on to implementation. Administrative Science Quarterly, 66(2), 380-425. https://doi.org/10.1177/0001839220962795

Schein, E. H. (2013). On communication: Process consultation, helping, and humble inquiry. Reflections: The SoL Journal, 13(2), 10-13.

Selig, J. P., \& Preacher, K. J. (2008, June). Monte Carlo method for assessing mediation: An interactive tool for creating confidence intervals for indirect effects [Computer software]. Available from http://quantpsy.org/

Sherf, E. N., Sinha, R., Tangirala, S., \& Awasty, N. (2018). Centralization of member voice in teams: Its effects on expertise utilization and team performance. Journal of Applied Psychology, 103(8), 813-827. https://doi.org/10.1037/ap10000305

Sherf, E. N., Tangirala, S., \& Venkataramani, V. (2019). Why managers do not seek voice from employees: The importance of managers' personal control and long-term orientation. Organization Science, 30(3), 447-466. https://doi.org/10.1287/orsc.2018.1273

Soenen, G., Melkonian, T., \& Ambrose, M. L. (2017). To shift or not to shift? Determinants and consequences of phase shifting on justice judgments. Academy of Management 
Journal, 60(2), 798-817. https://doi.org/10.5465/amj.2014.0181

Strickland, L. H. (1958). Surveillance and trust. Journal of Personality, 26(2), 200-215. https://doi.org/10.1111/j.1467-6494.1958.tb01580.x

Tangirala, S., \& Ramanujam, R. (2012). Ask and you shall hear (but not always): Examining the relationship between manager consultation and employee voice. Personnel Psychology, 65(2), 251-282. https://doi.org/10.1111/j.1744-6570.2012.01248.x

Trope, Y. (1986). Identification and inferential processes in dispositional attribution. Psychological Review, 93(3), 239-257. https://doi.org/10.1037/0033-295X.93.3.239

Trope, Y., Cohen, O., \& Maoz, Y. (1988). The perceptual and inferential effects of situational inducements on dispositional attribution. Journal of Personality and Social Psychology, 55(2), 165-177. https://doi.org/10.1037/0022-3514.55.2.165

Tskhay, K. O., Zhu, R., \& Rule, N. O. (2017). Perceptions of charisma from thin slices of behavior predict leadership prototypicality judgments. The Leadership Quarterly, 28(4), 555562. https://doi.org/10.1016/j.leaqua.2017.03.003

Van Dyne, L., \& LePine, J. A. (1998). Helping and voice extra-role behaviors: Evidence of construct and predictive validity. Academy of Management Journal, 41(1), 108-119. https://doi.org/10.5465/256902

Van Quaquebeke, N., \& Felps, W. (2018). Respectful inquiry: A motivational account of leading through asking questions and listening. Academy of Management Review, 43(1), 5-27. https://doi.org/10.5465/amr.2014.0537

Vroom, V. H., \& Jago, A. G. (1988). The new leadership: Managing participation in organizations. Englewood Cliffs, NJ: Prentice Hall.

Wang, L., Owens, B. P., Li, J. J., \& Shi, L. (2018). Exploring the affective impact, boundary conditions, and antecedents of leader humility. Journal of Applied Psychology, 103(9), 10191038. https://doi.org/10.1037/ap10000314

Whiting, S. W., Maynes, T. D., Podsakoff, N. P., \& Podsakoff, P. M. (2012). Effects of message, source, and context on evaluations of employee voice behavior. Journal of Applied Psychology, 97(1), 159-182. https://doi.org/10.1037/a0024871

Williams, L. J., \& Anderson, S. E. (1991). Job satisfaction and organizational commitment as predictors of organizational citizenship and in-role behaviors. Journal of Management, 17(3), 601-617. https://doi.org/10.1177/014920639101700305

Wrzesniewski, A., \& Dutton, J. E. (2001). Crafting a job: Revisioning employees as active crafters of their work. Academy of Management Review, 26(2), 179-201. https://doi.org/10.5465/amr.2001.4378011 


\section{Table 1}

Descriptive Statistics of Managerial Attributions of Employee Proactivity by Condition (Study 1)

\begin{tabular}{ccc}
\hline Condition & $\begin{array}{c}\text { Low employee } \\
\text { voice }\end{array}$ & $\begin{array}{c}\text { High employee } \\
\text { voice }\end{array}$ \\
\hline Low managerial & & \\
voice solicitation & & 5.83 \\
$M$ & 3.39 & 0.92 \\
$S D$ & 1.18 & 148 \\
$n$ & 146 & \\
High managerial & & 4.93 \\
voice solicitation & & 1.11 \\
$M$ & 3.78 & 148 \\
$S D$ & 1.14 & 0.88 \\
$n$ & 150 & \\
Cohen's $d$ & 0.34 &
\end{tabular}

Note. Cohen's $d$ reflects the effect size of the differences between the two managerial voice solicitation conditions within each of the two voice conditions. 


\section{Table 2}

Regression Analysis for Managerial Attributions of Employee Proactivity as the Mediator and Employee Job Rewards as the Dependent Variable (Study 1)

\begin{tabular}{|c|c|c|c|c|}
\hline \multirow[b]{2}{*}{ Variables } & \multicolumn{3}{|c|}{$\begin{array}{c}\text { Managerial Attributions of } \\
\text { Employee Proactivity }\end{array}$} & \multirow{2}{*}{$\begin{array}{c}\text { Employee Job } \\
\text { Rewards } \\
\text { Model } 4\end{array}$} \\
\hline & Model 1 & Model 2 & Model 3 & \\
\hline Intercept & $3.59^{* *}(0.07)$ & $3.72^{* *}(0.08)$ & $3.39^{* *}(0.09)$ & $1.49^{* *}(0.15)$ \\
\hline \multicolumn{5}{|l|}{ Independent Variables } \\
\hline Employee voice $(\mathrm{EV})^{\mathrm{a}}$ & $1.79^{* *}(0.09)$ & $1.79^{* *}(0.09)$ & $2.44^{* *}(0.13)$ & $0.83^{* *}(0.10)$ \\
\hline Managerial voice solicitation $(\mathrm{VS})^{\mathrm{b}}$ & & $-0.26^{* *}(0.09)$ & $0.38^{* *}(0.13)$ & \\
\hline \multicolumn{5}{|l|}{ Interaction } \\
\hline $\mathrm{EV} \times \mathrm{VS}$ & & & $-1.28^{* *}(0.18)$ & \\
\hline \multicolumn{5}{|l|}{ Mediator Variable } \\
\hline $\begin{array}{l}\text { Managerial attributions of } \\
\text { employee proactivity }\end{array}$ & & & & $0.58^{* *}(0.04)$ \\
\hline$R^{2}$ & $.38^{* *}$ & $.39^{* *}$ & $.44^{* *}$ & $.62^{* *}$ \\
\hline$\Delta R^{2}$ & - & $.01^{* *}$ & $.05^{* *}$ & - \\
\hline
\end{tabular}


Voice, Rewards, and Proactivity Attributions

Table 3

Descriptive Statistics, Correlations, and Reliabilities (Study 2)

\begin{tabular}{|c|c|c|c|c|c|c|c|c|c|c|}
\hline Variables & $M$ & $S D$ & 1 & 2 & 3 & 4 & 5 & 6 & 7 & 8 \\
\hline 1. Employee gender ${ }^{\mathrm{a}}$ & 0.86 & 0.35 & & & & & & & & \\
\hline 2. Employee age & 29.52 & 5.39 & $.14^{* *}$ & & & & & & & \\
\hline 3. Employee voice (manager-rated) & 3.22 & 0.98 & $.14^{* *}$ & .03 & $(.93)$ & & & & & \\
\hline 4. Managerial voice solicitation (employee-rated) & 3.93 & 1.12 & -.05 & -.05 & $.15^{* *}$ & $(.92)$ & & & & \\
\hline $\begin{array}{l}\text { 5. Employee voice } \mathrm{X} \text { managerial voice solicitation } \\
\text { (interaction) }\end{array}$ & 0.13 & 0.83 & .08 & .06 & -.03 & -.06 & & & & \\
\hline $\begin{array}{l}\text { 6. Managerial attributions of employee proactivity } \\
\text { (manager-rated) }\end{array}$ & 3.77 & 0.90 & .04 & -.01 & $.73^{* *}$ & $.22^{* *}$ & $-.10^{*}$ & $(.89)$ & & \\
\hline 7. Employee job rewards (manager-rated) & 3.53 & 0.85 & .08 & .03 & $.66^{* *}$ & $.16^{* *}$ & -.02 & $.71^{* *}$ & $(.87)$ & \\
\hline $\begin{array}{l}\text { 8. Employee job rewards one year later } \\
\text { (manager-rated })\end{array}$ & 3.92 & 0.88 & .06 & -.12 & $.29^{* *}$ & .11 & .02 & $.34^{* *}$ & $.40^{* *}$ & $(.86)$ \\
\hline
\end{tabular}

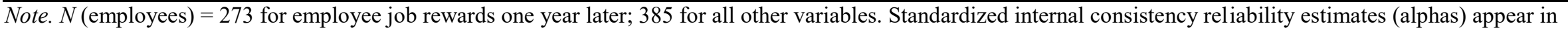

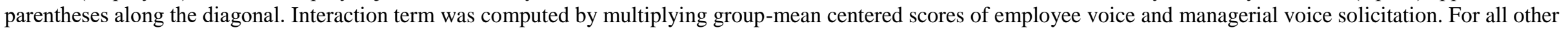
variables, raw correlations with uncentered values are reported.

${ }^{\text {a }}$ Dummy coded: $0=$ female, $1=$ male.

${ }^{*} p<.05 .{ }^{* *} p<.01$. 


\section{Table 4}

Regression Analysis for Managerial Attributions of Employee Proactivity as the Mediator and Employee Job Rewards as the Dependent Variable (Study 2)

\begin{tabular}{|c|c|c|c|c|}
\hline \multirow[b]{2}{*}{ Variables } & \multicolumn{3}{|c|}{$\begin{array}{l}\text { Managerial Attributions of } \\
\text { Employee Proactivity }\end{array}$} & \multirow{2}{*}{$\begin{array}{c}\text { Employee Job } \\
\text { Rewards } \\
\text { Model } 4 \\
\end{array}$} \\
\hline & Model 1 & Model 2 & Model 3 & \\
\hline Intercept & $3.80^{* *}(0.09)$ & $3.80^{* *}(0.09)$ & $3.81^{* *}(0.09)$ & $3.57^{* *}(0.08)$ \\
\hline \multicolumn{5}{|l|}{ Independent Variables } \\
\hline Employee voice (EV) & $0.70^{* *}(0.03)$ & $0.69^{* *}(0.03)$ & $0.69^{* *}(0.03)$ & $0.24^{* *}(0.04)$ \\
\hline Managerial voice solicitation (VS) & & $0.06^{*}(0.03)$ & $0.06^{*}(0.03)$ & \\
\hline \multicolumn{5}{|l|}{ Interaction } \\
\hline $\mathrm{EV} \times \mathrm{VS}$ & & & $-0.09^{*}(0.04)$ & \\
\hline \multicolumn{5}{|l|}{ Mediator Variable } \\
\hline $\begin{array}{l}\text { Managerial attributions of } \\
\text { employee proactivity }\end{array}$ & & & & $0.51^{* *}(0.05)$ \\
\hline$\sim R^{2}$ & .55 & .56 & .57 & .60 \\
\hline$\sim \Delta R^{2}$ & - & .00 & .01 & - \\
\hline
\end{tabular}

Note. $N$ (employees) $=385 ; N$ (groups) $=30$. Model reflects unstandardized regression coefficients with standard errors in parentheses. Employee voice and managerial voice solicitation are group-mean centered.

$\sim R^{2}$ : pseudo $R$-squared.

${ }^{*} p<.05 .{ }^{* *} p<.01$. 


\section{Figure 1}

Overall Theoretical Model

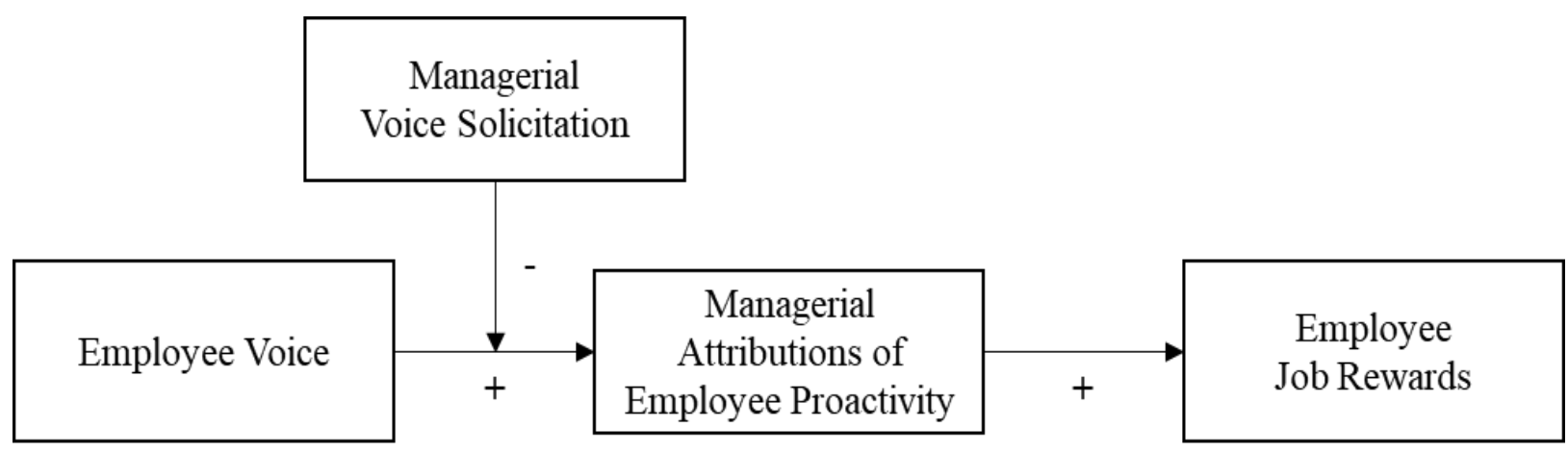




\section{Figure 2}

Interaction of Employee Voice and Managerial Voice Solicitation on Managerial Attributions of Employee Proactivity (Study 1)

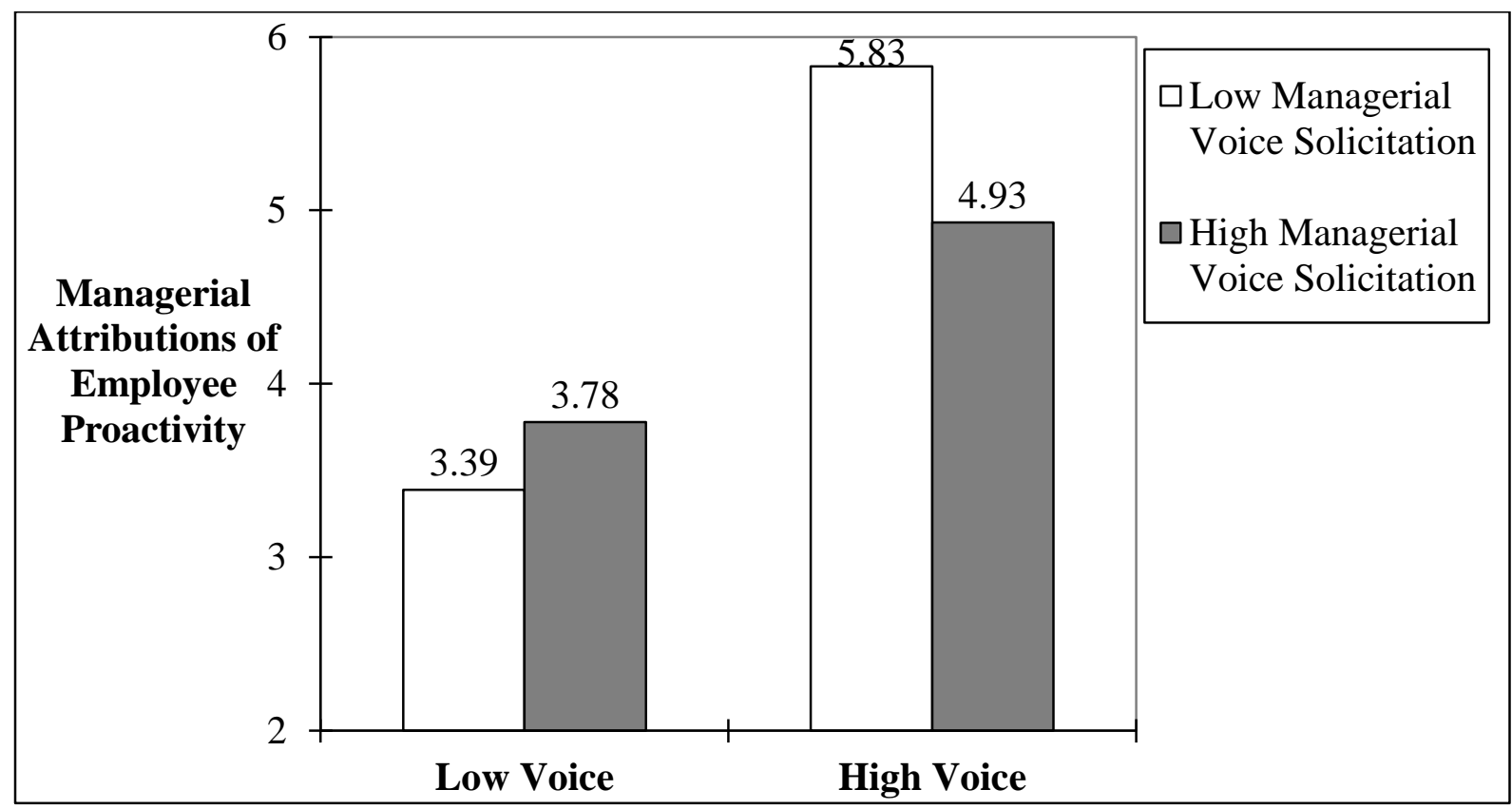


Figure 3

Simple Slopes for Managerial Attributions of Employee Proactivity (Study 2)

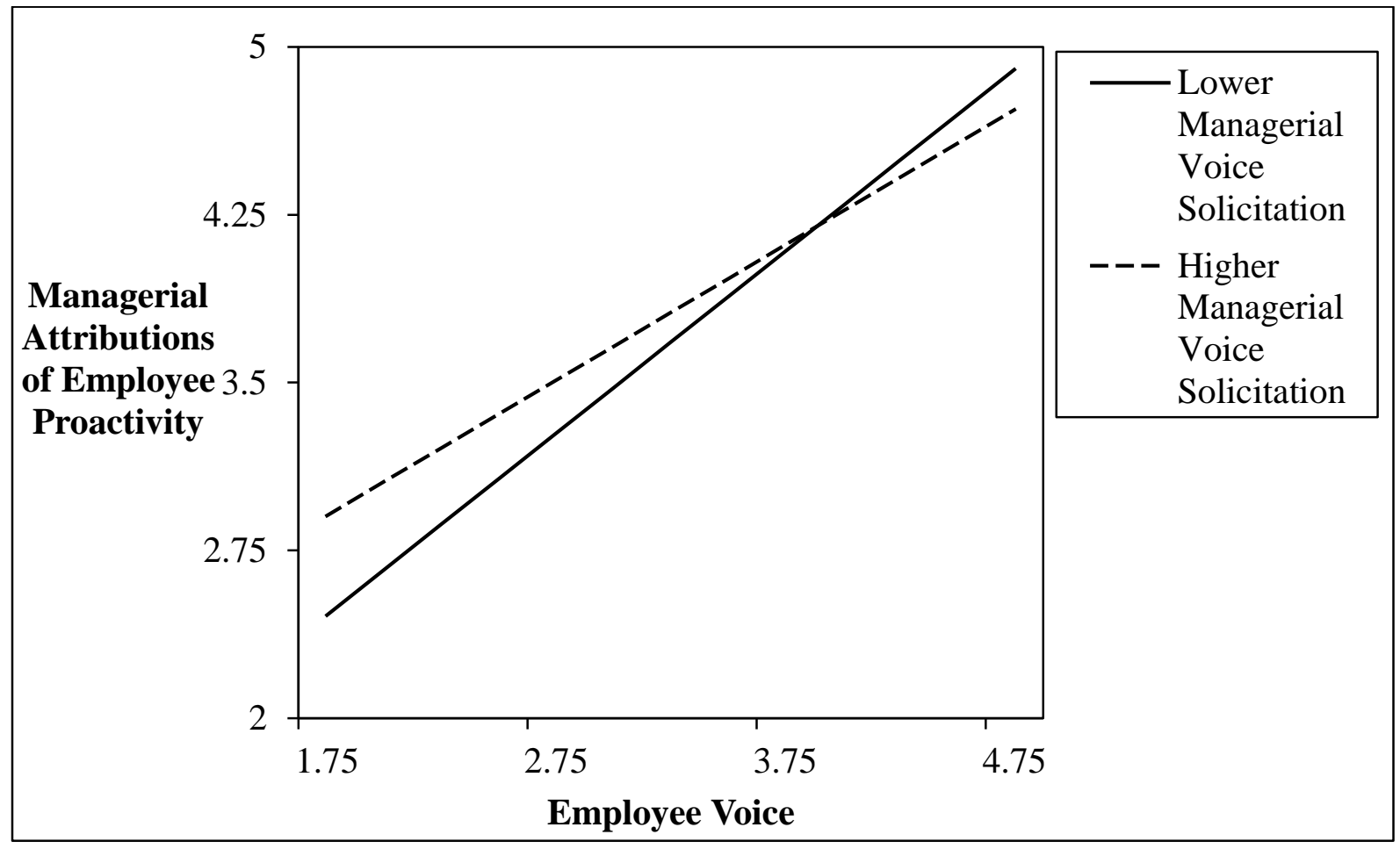

